\title{
62. PALYNOLOGICAL INVESTIGATION OF SAMPLES FROM HOLES 319, 320, 320A AND SITE 321 OF DSDP LEG 34
}

\author{
Julie F. Wiseman, West Australian Petroleum Pty. Limited, Perth, Western Australia
}

\begin{abstract}
Thirty samples from Sites 319, 320, and 321 were prepared for palynological investigation. Of these, only six, all of Quaternary age, yielded assemblages of identifiable palynomorphs. Although the assemblages are small, they are comparable with material from the Carribean Sea recorded by Wall (1967).
\end{abstract}

\section{INTRODUCTION}

Twelve samples were prepared from DSDP Hole 319, 7 from Holes 320 and 320A, and 11 from Site 321 for palynological investigation. All of the samples from Hole 319 were found to be barren of identifiable palynomorphs. Three of the samples from Holes 320 and 320A yielded small but varied palynomorph assemblages. The uppermost two samples from Site 321 contained palynomorphs in small numbers, the other samples from this site were barren. These sample data are summarized in Table 1 .

\section{DISCUSSION}

Approximately $5 \mathrm{~g}$ of each sample were prepared using standard palynological techniques, the carbonate fraction being removed by solution in hydrochloric acid and the silicate fraction in hydrofluoric acid. Where possible, clays and claystones were chosen for preparation in preference to carbonates. However, most of the samples contained a considerable carbonate fraction, demonstrated by generally vigorous reactions after the addition of hydrochloric acid. Only those samples that produced a weak reaction with hydrochloric acid contained recognizable palynomorphs, suggesting that the presence of carbonates had been detrimental to palynomorph preservation. Alternatively, the conditions giving rise to carbonate sedimentation may have precluded the occurrence of palynomorphs. A third factor possibly affecting palynomorph occurrence is distance from the shoreline of western South America. None of the samples from Hole 319 contained palynomorphs and this hole is considerably further away from the coast than Hole 320 and Site 321. The absence of palynomorphs from Hole 319 could be related to the low plankton productivity of the oceans in the vicinity of this hole combined with the improbability of landderived spores and pollen being transported over such a great distance. The oceanic and wind currents prevailing in this area are not favorable for such transport and, in addition, pollen and spore production will be generally low in the desert regions typical of much of the west coast of South America.

\section{Hole 319}

All of the samples studied were barren of recognizable palynomorphs.

\section{Hole 320}

Sample 320-1-2, 29-31 cm: from $5 \mathrm{~g}$ of sample only 15 specimens were recovered. The microfloral assemblage was as follows:

Chytroeisphaeridia sp. cf. C. cariacoensis Wall, 1967

Spiniferites ramosus (Ehrenberg) Loeblich and

Loeblich, 1966

Dinoflagellate gen. et sp. indet.

Graminaceae pollen

Lycopodiales gen. et sp. indet.

Foraminiferan tests

The other samples from this site were found to be barren of recognizable palynomorphs.

\section{Hole 320A}

Sample 320A-1-1, 0-5 cm: $5 \mathrm{~g}$ of sample yielded 27 specimens. The microfloral assemblage was as follows:

Leptodinium paradoxum Wall, 1967

Nematosphaeropsis sp.

Operculodinium centrocarpum (Deflandre and

Cookson) Wall, 1967

O. sp. cf. O. israelianum (Rossignol) Wall, 1967

Spiniferites ramosus (Ehrenberg) Loeblich and

Loeblich, 1966

Chytroeisphaeridia sp.

Graminaceae pollen

Disaccate pollen

Lycopodiales gen. et sp. indet.

The other samples studied from this site were found to be barren of identifiable palynomorphs.

\section{Site 321}

Sample 321-2-3, 118-120 cm: $5 \mathrm{~g}$ of sample yielded 11 specimens. The microfloral assemblage was as follows:

Leptodinium sp. cf. L. aculeatum Wall, 1967

L. paradoxum Wall, 1967

L. sphaericum Wall, 1967

Spiniferites ramosus (Ehrenberg) Loeblich and Loeblich, 1966

Sample 321-3-4, 70-72 cm: 5. g of sample yielded 20 specimens. The microfloral assemblage was as follows: Achomosphaera hypercantha (Deflandre and Cookson) Davey and Williams, 1969.

Spiniferites ramosus (Ehrenberg) Loeblich and Loeblich, 1966

Leptodinium paradoxum Wall, 1967 
TABLE 1

Summary of Palynological Investigations, Leg 34

\begin{tabular}{c|c|c|c|c|c|c|c}
\hline \multicolumn{2}{c|}{ Hole 319} & \multicolumn{2}{c|}{ Hole 320 } & \multicolumn{2}{c|}{ Hole 320A } & \multicolumn{2}{c}{ Site 321 } \\
\hline $\begin{array}{c}\text { Core- } \\
\text { Section }\end{array}$ & Yield & $\begin{array}{c}\text { Core- } \\
\text { Section }\end{array}$ & Yield & $\begin{array}{c}\text { Core- } \\
\text { Sectiona }\end{array}$ & Yield & $\begin{array}{c}\text { Core- } \\
\text { Section }\end{array}$ & Yield \\
\hline $1-4$ & B b & $1-0$ & $\sqrt{ }$ a & $1-1 \mathrm{a}$ & $\checkmark$ & $2-3$ & $\checkmark$ \\
$2-3$ & B & $2-2$ & B & $1-1 \mathrm{~b}$ & $\checkmark$ & $3-4$ & $\checkmark$ \\
$3-3$ & B & $3-6$ & ?d & $1-1 \mathrm{c}$ & B & $4-4$ & $\checkmark$ \\
$4-1$ & B & & & $2-4$ & B & $5-5$ & B \\
$5-6$ & B & & & & & $6-3$ & B \\
$6-3$ & B & & & & & $7-3$ & $?$ \\
$7-6$ & B & & & & & $8-3$ & B \\
$8-2$ & B & & & & & $10-3$ & B \\
$9-3$ & B & & & & & $11-3$ & B \\
$10-5$ & B & & & & & $13-3$ & B \\
$11-3$ & B & & & & & & \\
$12-2$ & B & & & & & \\
\hline
\end{tabular}

${ }^{a}$ Samples from same section of core denoted by 1a, 1b, 1c.

$\mathrm{b}_{\mathrm{B}}=$ Barren of identifiable palynomorphs.

c $\checkmark$ Palynological assemblages recovered

$\mathrm{d}_{?}=$ Single specimens recorded (considered to be barren).

L. aculeatum Wall, 1967

L. sphaericum Wall, 1967

Chytroeisphaeridia sp.

Tasmanites sp.

Graminaceae pollen

Sample 321-4-4, 101-103 cm: $6.5 \mathrm{~g}$ of sample yielded 12 specimens. The microfloral assemblage was as follows:

Leptodinium paradoxum Wall, 1967

L. sphaericum Wall, 1967

L. sp. cf. L. aculeatum Wall, 1967

Achomosphaera sp.

Nematosphaeropsis sp.

The other samples studied from this site were found to be barren of identifiable palynomorphs.

The samples from Holes 319, 320, and 320A and Site 321 which yielded identifiable palynomorphs are all Quaternary in age. The dinoflagellates found, although few in number, compare with the microplankton of the same age recorded by Wall (1967) in deep-sea cores from the Carribean Sea. Insufficient numbers of palynomorphs were recovered to allow statistical analysis of the assemblages. The low yields were probably caused by a combination of geographical location and sedimentary environments unsuitable for the preservation of palynomorphs. However, it should be noted that those dinoflagellates that were recognized were all in an ex- cellent state of preservation. There are two possible sources of the cysts. They could have been introduced from encystment of dinoflagellates living in the vicinity of the sites. Samples from the ocean surface at Site 321 yielded several species of Gonyaulax, Ceratium, and Peridinium, showing that conditions are favorable to support phytoplankton. Alternatively, the cysts could have been introduced by reworking of palynomorphbearing sediments into the area. Unfortunately, insufficient data are available to decide which of these sources is most likely. However, the presence of pollen and spores does require transport over long distances, either by ocean currents at the surface or reworking of sediments. This would suggest the possibility that the dinoflagellate cysts have also been derived from sources not in the immediate vicinity of the sites.

\section{ACKNOWLEDGMENTS}

The author would like to thank Patrick G. Quilty of West Australian Petroleum who suggested this study and offered much helpful information and encouragement. Thanks also to Murray H. Johnstone and Alan J. Williams for help and constructive criticism and to Christine Howard who prepared the material.

\section{REFERENCE}

Wall, D., 1967. Fossil microplankton in deep sea cores from Carribean Sea: Palaeontology, v. 10, p. 95-123. 